\title{
Direct immunofluorescence in Lupus Erythematosus (LE)
}

\author{
Study performed at the General Hospital Dermatology Clinic of the \\ University of São Paulo Medical School - São Paulo.
}

\begin{abstract}
One hundred and twenty-six patients with LE were studied. They were distributed as follows: 84 with DLE, 13 with SALE and 29 with SLE. Biopsies from the skin lesions were performed and submitted to DIF. Positive results were equal to $69,61.5$ and 72.4 percent of the DLE, SALE and SLE cases, respectively. These data are in accordance with the literature. IgM was the most frequently found immunoglobulin, followed by the association IgM+C3.
\end{abstract}

UNITERMS: Direct immunofluorescence (DIF). Lupus erythematosus (LE). Discoid lupus erythematosus (DLE). Subacute lupus erythematosus (SALE). Systemic lupus erythematosus (SLE). Immunoglobulins (Igs).

\section{INTRODUCTION}

I mmunoglobulin (Ig) and complement (C3) deposits, detected by the direct immunofluorescence technique (DIF) at the dermoepidermal junction of skin lesions from patients with lupus erythematosus (LE), were first described by BURHAM et al. in $1963 .{ }^{4}$ Later, CORMANE ${ }^{5}$ demonstrated that such deposits also occurred in clinically-normal skin of patients with systemic lupus erythematosus (SLE), but were not found in normal skin of patients with discoid lupus erythematosus (DLE).

Since then, a number of studies have been undertaken which lead to the conclusion that immunoglobulin deposits in the skin in the basal membrane zone (BMZ) are

\section{Address for correspondence:}

Roseli Svartman Isfer

Rua Diana, 1039 - apto. 123 - Vila Pompéia

São Paulo/SP - Brasil - CEP 05019-000 characteristic of LE, thus having diagnostic, and possibly, prognostic value.

The present study evaluates the incidence of positive DIF in skin lesions of patients with discoid lupus erythematosus (DLE), subacute lupus erythematosus (SALE) and systemic lupus erythematosus (SLE), as well as the incidence of different immunoglobulins (Igs) and of complement (C3).

\section{MATERIAL AND METHODS}

One hundred and twenty-six patients with LE, treated at the General Hospital Dermatology Clinic of the University of São Paulo Medical School between 1990 and 1992, were retrospectively studied. The patients were distributed as follows: 84 with DLE, 13 with SALE and 29 with SLE. The classification of the patients into these subgroups was based on clinical, histopathologic and 


\section{DISCOID LUPUS ERYTHEMATOUS}

SEX DISTRIBUTION

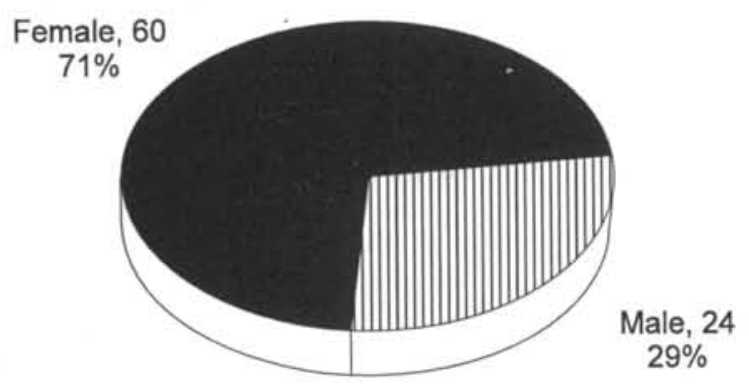

Figure 1 - Discoid Lupus Erythematosus - Sex distribution.

serologic data. The patients with SLE fulfilled at least four of the American Rheumatism Association (ARA) criteria. ${ }^{15}$

The three study groups were predominantly female, with different relative frequencies within each group (Figs. 1,2 and 3). The patient's ages ranged from 6 to 79 years with a majority in their 30's (Figs. 4, 5 and 6).

Punch biopsies of skin lesions were performed on the 126 patients. The tissue fragments were immediately frozen, cut into $5 \mathrm{~mm}$-thick sections and incubated with fluorescein-labeled antibodies in a moist chamber at room temperature for 30 minutes. The sections were then washed twice (for 10 minutes) with TBS ( $\mathrm{pH} 7.5)$, and covered with phosphate-buffered glycerine ( $\mathrm{pH} 9.0)$. The specimens were examined with a Zeiss epifluorescence-equipped microscope.
SYSTEMIC LUPUS ERYTHEMATOUS

SEX DISTRIBUTION

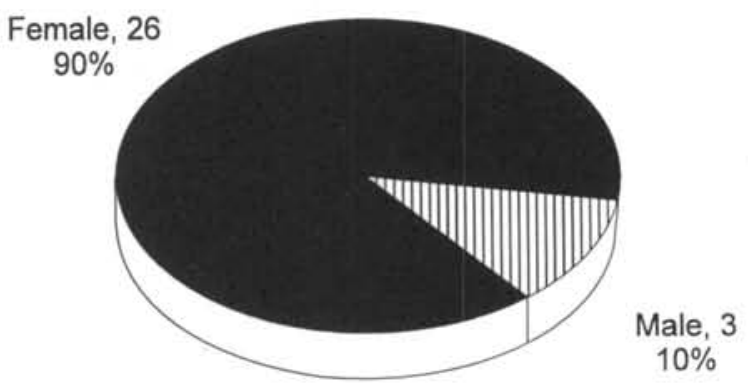

Figure 3 - Systemic Lupus Erythematosus - Sex distribution.

\section{RESULTS}

Positive DIF results in skin lesions were detected in 58 of 84 patients ( 69 percent) with DLE, 8 of 13 (61.5 percent) patients with SALE, and 21 of 29 (72.4 percent) patients with SLE. Immunoglobulins were found isolated or associated and with complement in the BMZ and also in the blood vessels, and in the form of cytoid bodies, as shown in Tables 1-6.

Among the DLE lesions with positive DIF, we verified the presence of $\mathrm{IgG}$ and/or complement in the BMZ in 56 ( 96.5 percent) patients. Of these, in 46 cases (79.3 percent), DIF was positive in the BMZ only, in 4 (6.9 percent), the deposit was also present in the blood

\section{SUBACUTE LUPUS ERYTHEMATOUS} SEX DISTRIBUTION

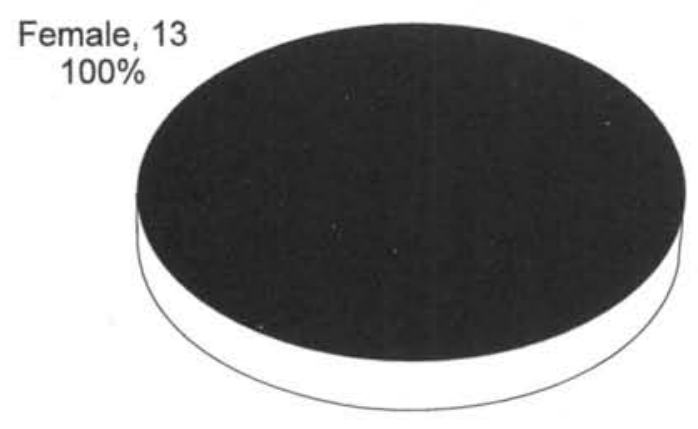

Figure 2 - Subacute Lupus Erythematosus Sex distribution.

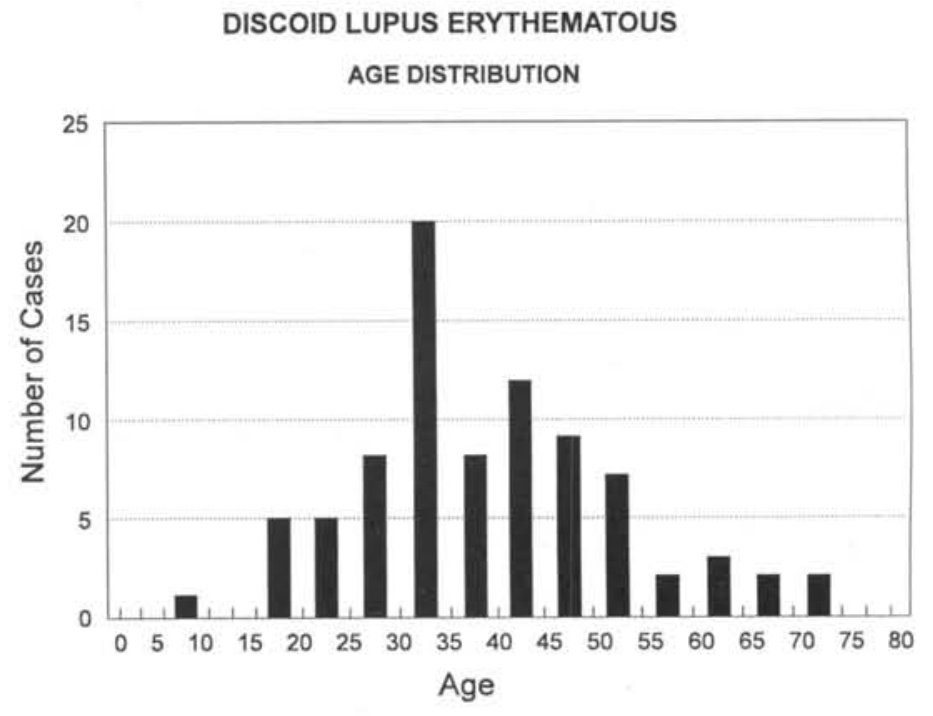

Figure 4 - Discoid Lupus Erythematosus - Age distribution. 
Table 1

IG and C3 in skin lesions of 58 patients with DLE and Positive DIF in the vessels and cytoid bodies

\begin{tabular}{l|c|c|c|c|c|c}
\hline Classes & $\begin{array}{c}\text { Isolated } \\
\text { vessels }\end{array}$ & $\begin{array}{c}\text { Vessels in } \\
\text { BMZ assoc. }\end{array}$ & Total & $\begin{array}{c}\text { Isolated } \\
\text { cytoid bodies }\end{array}$ & $\begin{array}{c}\text { Cytoid bodies } \\
\text { BMZ assoc. }\end{array}$ & Total \\
\hline IgM & 0 & 3 & 3 & 0 & 4 & 4 \\
IgM + IgA & 0 & 0 & 0 & 1 & 1 & 1 \\
IgM + C3 & 0 & 0 & 0 & 1 & 0 & 2 \\
C3 & 0 & 1 & 1 & 0 & $6(10.3 \%)$ & $8(13.8 \%)$ \\
\hline Total & 0 & $4(6.9 \%)$ & $4(6.9 \%)$ & $2(3.45 \%)$ & & \\
\hline
\end{tabular}

vessels, and in 6 (10.3 percent), in the cytoid bodies. In 2 patients (3.4 percent), DIF was positive only in the cytoid bodies.

The distribution of the different Igs and of $\mathrm{C} 3$ is shown in Tables 1 and 4. In the BMZ, IgM was the most common $\mathrm{Ig}$, followed by the association $\mathrm{IgM}+\mathrm{C} 3$ and $\mathrm{IgM}+\mathrm{IgG}+\operatorname{Ig} \mathrm{A}+\mathrm{C} 3 . \mathrm{C} 3$ was found isolated in the $\mathrm{BMZ}$ in 3 (5.2 percent) of the patients (Table 4$)$. The most commonly found Ig in the blood vessels and cytoid bodies was also IgM (Table 1).

In the 8 SALE patients with positive DIF, the BMZ was fluorescent, in 2 cases the vessels were also fluorescent, and in 1 patient there was fluorescence in the cytoid bodies (Table 2). Regarding the distribution of Igs in the BMZ (Table 5), there was predominance of $\mathrm{IgM}+\mathrm{C} 3$. IgM was found isolated in only 1 case.

Of the 21 patients with SLE and positive DIF, 18 (85.7 percent) showed deposits in the BMZ, 2 were also positive in the blood vessels, and 3 in the cytoid bodies. Isolated fluorescence in the vessels was found in 2 cases ( 9.5 percent), and in the cytoid bodies in 1 patient ( 4.8 percent) (Table 3 ). The Igs' distribution in the BMZ (Table 6) revealed predominance of $\mathrm{IgM}$ followed by $\mathrm{IgM}+\mathrm{C} 3$ and $\mathrm{IgG}+\mathrm{IgM}+\mathrm{IgA}+\mathrm{C} 3$. In one case, $\mathrm{C} 3$ was found isolated in the $\mathrm{BMZ}$. The presence of $\mathrm{IgM}+\mathrm{C} 3$ in the vessels was observed in one patient, and isolated C3 in another, where as in the cytoid bodies, $\operatorname{IgM}+\operatorname{IgG}$ were found isolated in only one case.

SUBACUTE LUPUS ERYTHEMATOUS AGE DISTRIBUTION

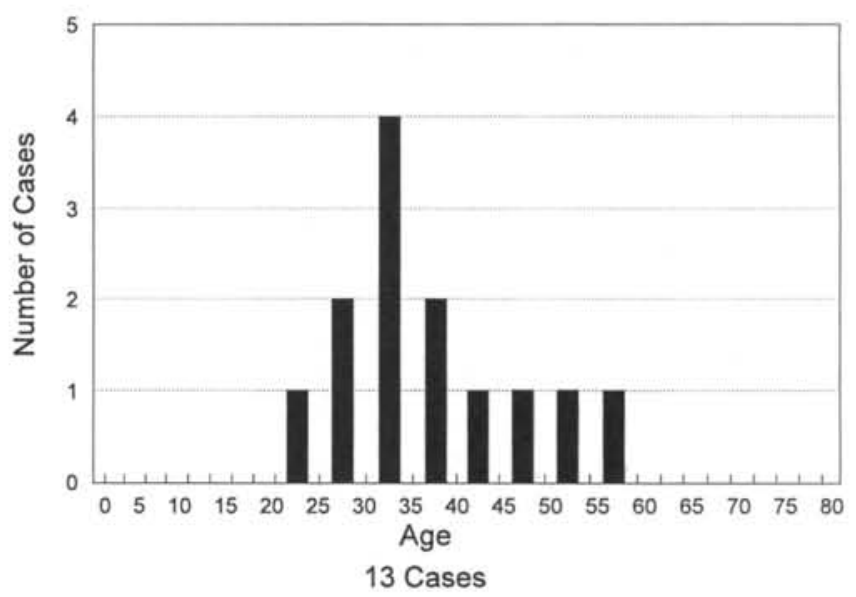

Figure 5 - Subacute Lupus Erythematosus - Age distribution.

Table 2

IG and C3 in skin lesions of 8 patients with Sale and Positive DIF in the vessels and cytoid bodies

\begin{tabular}{c|c|c|c|c}
\hline Classes & $\begin{array}{c}\text { Isolated } \\
\text { vessels }\end{array}$ & $\begin{array}{c}\text { Vessels in } \\
\text { BMZ assoc. }\end{array}$ & $\begin{array}{c}\text { Isolated } \\
\text { cytoid bodies }\end{array}$ & $\begin{array}{c}\text { Cytoid bodies } \\
\text { BMZ assoc. }\end{array}$ \\
\hline IgM & 0 & 1 & 0 & 4 \\
IgM + C3 & 0 & 1 & & \\
\hline Total & 0 & $2(25 \%)$ & 0 & $1(12.5 \%)$ \\
\hline
\end{tabular}


Table 3

IG and C3 in skin lesions of 21 patients with SLE and Positive DIF in the vessels and cytoid bodies

\begin{tabular}{c|c|c|c|c|c|c}
\hline Class & $\begin{array}{c}\text { Isolated } \\
\text { vessels }\end{array}$ & $\begin{array}{c}\text { Vessels in } \\
\text { BMZ assoc. }\end{array}$ & Total & $\begin{array}{c}\text { Isolated } \\
\text { cytoid bodies }\end{array}$ & $\begin{array}{c}\text { Cytoid bodies } \\
\text { BMZ assoc. }\end{array}$ & Total \\
\hline IgM & & & & 1 & 3 & 3 \\
$\operatorname{IgM}+\lg A$ & 1 & 1 & 2 & & 1 \\
C3 + C3 & 1 & 1 & 1 & & & \\
IgM+IgM+C3 & $02(9.5 \%)$ & $02(9.5 \%)$ & $4(19 \%)$ & $01(4.0 \%)$ & $03(19.3 \%)$ & $4(19.1 \%)$ \\
\hline Total & & & & & & \\
\hline
\end{tabular}

Table 4

IG and $\mathrm{C} 3$ in skin lesions of 58 patients with DLE and Positive DIF

\begin{tabular}{|c|c|c|c|}
\hline Classes & $\mathrm{BMZ}$ & Vessels & Cytoid bodies \\
\hline $\lg G$ & $3(1)^{\star}$ & 0 & 0 \\
\hline $\lg G+C 3$ & 1 & 0 & 0 \\
\hline $\lg G+\lg M$ & 3 & 0 & 0 \\
\hline $\lg G+\lg A$ & $1^{\star \star}$ & 0 & 0 \\
\hline $\lg G+\lg M+C 3$ & 6 & 0 & 0 \\
\hline $\lg G+\lg A+C 3$ & 1 & 0 & 0 \\
\hline $\lg \mathrm{G}+\lg \mathrm{M}+\lg \mathrm{A}+\mathrm{C} 3$ & $7(1)^{n *}$ & 0 & 0 \\
\hline $\lg M$ & $17(3)^{*}$ & 0 & 0 \\
\hline $\lg M+C 3$ & $\begin{array}{c}7(2)^{* \star *} \\
(1)^{*}\end{array}$ & 0 & 0 \\
\hline $\lg M+\lg A$ & 0 & 0 & 1 \\
\hline $\lg M+\lg A+C 3$ & $4(1)^{\circ}$ & 0 & 0 \\
\hline $\lg A$ & 2 & 0 & 0 \\
\hline $\lg A+C 3$ & 1 & 0 & 1 \\
\hline \multirow[t]{2}{*}{ C3 } & 3 & 0 & 0 \\
\hline & $56(96.5 \%)$ & 0 & $2(3.5 \%)$ \\
\hline
\end{tabular}

* IgM fluorescence in cytoid bodies

** IgM and IgA fluorescence in cytoid bodies

*** IgM and C3 fluorescence in cytoid bodies

" IgM fluorescence in the vessels

"*t C3 fluorescence in the vessels

- IgM fluorescence in cyotid bodies and vessels

\section{DISCUSSION}

In a study performed by TUFFANELLI in 1975 , DIF was positive in 94 percent of DLE cases. ${ }^{17}$ The results of the present study (69 percent) agree with more recent studies such, as those of PROENÇA et al.,"10 in which DIF was positive in the skin lesions of 58.33 percent of the patients with DLE, and of BLASZCZYK and DAHL,${ }^{3}$ in which the positive results reached 79 percent. A study performed by SUGAI et al. at our clinic revealed positive results in 66.2 percent of these cases. ${ }^{14}$

Several factors may affect the positive result of DIF, such as the duration of the lesions, their

SYSTEMIC LUPUS ERYTHEMATOUS

AGE DISTRIBUTION

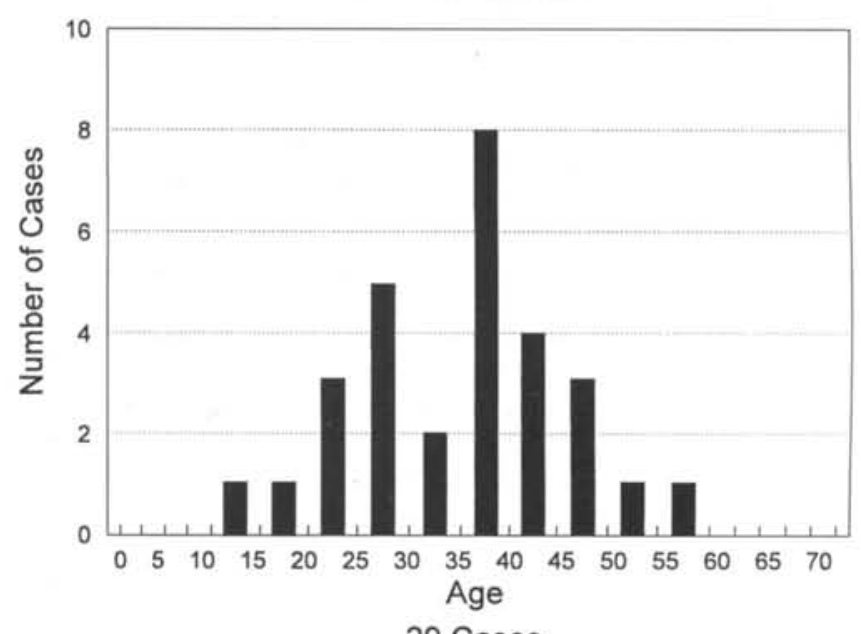

29 Cases

Figure 6 - Systemic Lupus Erythematosus - Age distribution. 
Table 5

IG and C3 in skin lesions of 8 patients with Sale and Positive DIF

\begin{tabular}{l|c|c|c|c}
\hline Class & BMZ & Vessels & Cytoid bodies & \\
\hline $\lg G+\lg M$ & 2 & & & 2 \\
$\lg G+\lg M+C 3$ & $2^{*}(1)$ & & & 2 \\
$\lg M$ & 1 & & & 1 \\
$\lg M+C 3$ & $3^{\star \star}(1)$ & & 3 \\
\hline & $8(100 \%)$ & & & $8(100 \%)$ \\
\hline
\end{tabular}

* IgM fluorescence in cytoid bodies

** IgM and C3 in the vessels

$\star \star \star$ IgM fluorescence in the vessels

\begin{tabular}{|c|c|c|c|c|}
\hline \multicolumn{5}{|c|}{$\begin{array}{c}\text { Table } 6 \\
\text { IG and C3 in skin lesions of } 21 \text { patients } \\
\text { with SLE and Positive DIF }\end{array}$} \\
\hline Class & $\mathrm{BMZ}$ & Vessels & Cytoid & \\
\hline $\lg G$ & 1 & & & 1 \\
\hline $\lg G+C 3$ & 1 & & & 1 \\
\hline $\lg G+\lg M$ & $2(1)^{*}$ & & 1 & 3 \\
\hline $\lg G+\lg M+\lg A$ & 1 & & & 1 \\
\hline $\lg G+\lg M+\lg A+C 3$ & $\begin{array}{l}3(1)^{\star \star} \\
(1)^{\star \star *}\end{array}$ & & & 3 \\
\hline $\lg M$ & 4 & & & 4 \\
\hline $\lg M+C 3$ & $3(1)^{\star}$ & 1 & & 4 \\
\hline $\lg M+\lg A+C 3$ & 1 & & & 1 \\
\hline $\lg M+\lg A$ & $1(1)^{*}$ & & & 1 \\
\hline \multirow[t]{2}{*}{$\mathrm{C} 3$} & 1 & 1 & & 2 \\
\hline & $18(85.7 \%)$ & $2(9.5 \%)$ & $1(4.8 \%)$ & $21(100 \%)$ \\
\hline
\end{tabular}

* IgM fluorescence in cytoid bodies

** IgG, IgM and C3 fluorescence in the vessels

*** C3 fluorescence in the vessels

distribution (exposed or unexposed area) and previous treatment. ${ }^{3}$ In the present study, the biopsies were always taken from exposed skin lesions. Nevertheless, the duration of the lesions and the prebiopsy treatment period could not be analyzed.

SALE lesions were DIF positive in 61.5 percent of the cases, which coincides with the 60 percent found by SONTHEIMER et al. ${ }^{13}$ It was not possible to classify the patients according to the aspect of the lesions (annular or papulosquamous), which is important as, according to the same author, lesions of the papulosquamous type present $\mathrm{Ig}$ deposits at the dermoepidermal junction more frequently. Recently, a new DIF pattern in SALE, called "dust-like particles", was described by NIEBOER et al. and considered highly specific but had low sensitivity. ${ }^{9}$ This pattern was not taken into account in the present study.

In SLE skin lesions, the positive results of DIF reported in the literature varied from 50 percent ${ }^{11}$ to 93 percent. ${ }^{17}$ Thus, our result of 72.4 percent agrees with the previous data.

In a study performed by AHMED and PROVOST in 1979, ${ }^{1}$ who analyzed DIF results in normal exposed and unexposed skin of patients with SLE, positive results reached 77 and 37 percent, respectively. We believe that the higher positive results observed by us may be due to the fact that biopsies were always performed on exposed skin.

The positive DIF in the three study groups was almost always observed in the BMZ. Isolated fluorescence in the blood vessels occurred in 9.5 percent of the SLE cases, and did not occur in the DLE and SALE patients.

These findings confirm the literature data, which states that Ig deposits in the vessels are more frequently observed in SLE. Nevertheless, our frequency of positive results is lower than the one described in the literature, which varied from 30 to 95 percent $^{6}$ when clinically normal skin was considered. These differences may be related to the fact that DIF was only considered positive when the vessel wall was well-defined. Besides, as we 
performed a retrospective study, it was not possible to determine how many patients were already under treatment at the time of biopsy.

The isolated fluorescence of the cytoid bodies was not frequent: 3.4 percent in DLE, 0 percent in SALE and 4.8 percent in SLE. It seems to present low specificity, and may occur in the photo damaged skin and, thus, have a non-immunological origin. ${ }^{19}$

The most frequently found Ig in the BMZ, alone or in association with other Igs and/or C3, was IgM, in the three study groups. In SALE, IgM was found in 100 percent of the cases.

According to previous research, there is predominance of IgM or IgG. TUFFANELLI, in a study of 971 cases, found a predominance of $\mathrm{IgG}^{18}{ }^{18}$ while other authors, studying smaller samples, found a predominance of IgM. . $^{7.16 .19}$ According to HARRIST and MIHM, it seems proper to conclude, in view of the small number of patients in the studies involving a predominance of $\mathrm{IgM}$, that the presence of $\mathrm{IgM}$ alone is uncommon. ${ }^{6}$ Many authors agree that IgM is more sensitive, while $\mathrm{IgG}$ is more specific. ${ }^{2}$

C3 was generally found in association with these Igs, and seldom isolated. In the literature, the presence of C3 is considered suggestive of the classic pathway activation of the complement. ${ }^{\text {? }}$

The most frequently reported association is $\mathrm{IgG}+\mathrm{IgM},{ }^{3.8}$ an association not verified in the present study, whereas the $\mathrm{IgM}+\mathrm{C} 3$ association was more frequent. In a study performed by RATNAM et al. in Singapore, ${ }^{12} \mathrm{C} 1 \mathrm{q}$ was the most frequently found immunoreactant, followed by $\operatorname{IgM}$.

\section{CONCLUSION}

DIF has a very important role in LE diagnosis. The results of the present study show that, although there are several variables of a racial, climatic and technical order, it was possible to reproduce the frequencies of positive results reported in the international literature.

It is important to stress that DIF, as any laboratory procedure, has limitations and must always be considered together with clinical, serologic and histopathological data.

\section{Resumo}

Foram estudados cento e vinte e seis pacientes com LE, distribuidos da seguinte forma: 84 com LED, 13 com LESA e 29 com LES. Foram realizadas biópsias na pele lesada, que foram submetidas a IFD. Houve positividade de $69 \%$ para o LED, $61,5 \%$ para o LESA e $72,4 \%$ para o LES, dados estes que estāo de acordo com a literatura. IgM foi a lg mais freqüentemente encontrada, seguida da associação $\lg \mathrm{M}+\mathrm{C} 3$. 


\section{REFERENCES}

1. Ahmed AR, Provost TT. Incidence of a positive lupus band test using sun-exposed and unexposed skin. Arch Dermatol 1979;115:228-9.

2. Baart F, Kuyper EH, Cormane RH. The occurrence of certain serum factors in the dermal-epidermal junction and vessel walls of the skin in lupus erythematosus and other skin diseases. Acta Dermatovener 1968;48:578-88.

3. Blaszczyk M, Dahl MV. Usefulness of direct immunofluorescence in patients with lupus erythematosus. Arch Dermatol 1983;119:1010-7.

4. Burham TK, Neblett TR, Fine G. The application of the fluorescent antibody technique to the investigation of lupus erythematosus and various dermatoses. J Invest Dermatol 1963;41:451-6.

5. Cormane RH. "Bound" globulin in the skin of patients with chronic discoid lupus erythematosus and systemic lupus erythematosus. Lancet 1964;1:534-5.

6. Harrist TJ, Mihm MC. The specificity and clinical usefulness of the lupus band test. Arthritis Rheum 1980;23(4):479-90.

7. Jordon RE, Schroeter AL, Winkelman RK. Dermalepidermal deposition of complement components and properdin in systemic lupus erythematosus. Brit J Dermatol 1975;92:263-71.

8. Monroe EW. Lupus band test. Arch Dermatol 1977;113:830-4.

9. Nieboer C, Tak-Diamand Z, Van Leeuwen-Wallau HE, Dust-like particles: a specific direct immunofluorescence pattern in sub-acute cutaneous lupus erythematosus. Brit J Dermatol 1988;118:725-34

10. Proença NG, Machado ER, Paes RP. Bernardes MP. Reavaliação dos resultados obtidos com a técnica de imunofluorescência direta em lesão de lupus eritematoso discóide. An Bras Dermatol 1985;60:303-6.

11. Provost TT. Lupus band test. Int J Dermatol 1981;20:475-81.

12. Ratnam KV, Phay KL, Ng SK, Tan T. Skin immunofluorescence patterns in SLE patients in Singapore. Singapore Med J 1987;6:517-9.

13. Sontheimer RD, Thomas JR, Gilliam JN. Subacute cutaneous lupus erythematosus. Arch Dermatol 1979;115:1409-15.

14. Sugai AS, Gerbase AB, Cernea SS, et al. Cutaneous lupus erythematosus: direct immunofluorescence and epidermal basal membrane study. Int J Dermatol 1992;31(4):260-4.

15. Tan EM, Choen AS, Fries JF, et al. The 1982 revised criteria for the classification of systemic lupus erythematosus. Arthr and Rheum 1975;25:1271.

16. Ten Have-Opbraek AAW. Demonstration of immunoglobulin and complement in the skin of patients with lupus erythematosus. Acta Dermatovener 1966;46:68-71.

17. Tuffanelli DL. Cutaneous immunopathology. Recent observations. J Invest Dermatol 1975:65:143-53.

18. Tuffanelli DL. Clinical cutaneous immunopathology. J C E Dermatology 1978;16:19-39.

19. Weingand DA. Cutaneous immunofluorescence. Med Clin of North America 1989;73(5):1263-74. 